\title{
Food Availability and Food Hoarding Behaviour by Red and Arctic Foxes
}

\author{
B.O. SKLEPKOVYCH ${ }^{1,2}$ and W.A. MONTEVECCHI ${ }^{1}$
}

(Received 2 July 1992; accepted in revised form 6 March 1996)

\begin{abstract}
Both red and arctic foxes cache food. The present and previous studies have documented scatter hoarding (hiding single or small numbers of prey at dispersed sites) and larder hoarding (hiding many prey at or near den sites) by both species. Red foxes resident on an island with a large seabird community in Newfoundland, where food is superabundant in summer and scarce during winter, made large larder hoards over an eight-year period. Scat analyses revealed that hoarded prey were heavily utilized during winter. An arctic fox encountered on an offshore seabird island hoarded seabirds in larders. For both species, larder hoarding is associated with a superabundance of prey and appears to represent a flexible response to environmental conditions.
\end{abstract}

Key words: arctic fox, Alopex lagopus, behaviour, caching, food, hoarding, predation, red fox, Vulpes vulpes, seabirds

RÉSUMÉ. Le renard roux et le renard arctique font tous deux des réserves de nourriture. L'étude actuelle et des études précédentes documentent le stockage dispersé de réserves (le fait de cacher une proie unique ou quelques proies à des endroits dispersés) et le stockage en garde-manger (le fait de cacher un grand nombre de proies sur le site du terrier ou à proximité) par les deux espèces de renard. Les renards roux vivant dans une île qui possède une importante communauté d'oiseaux marins à Terre-Neuve, où il y a une abondance de nourriture en été et une pénurie en hiver, ont fait d'importantes réserves en garde-manger sur une période de huit ans. Des analyses d'excréments ont révélé que les proies stockées étaient consommées en grand nombre au cours de l'hiver. Un renard arctique rencontré dans une île en mer fréquentée par des oiseaux marins stockait ces derniers dans des garde-manger. Pour les deux espèces, le stockage en garde-manger est associé à une surabondance de proies et semble représenter une adaptation aux conditions prévalant dans le milieu ambiant.

Mots clés: renard arctique, Alopex lagopus, comportement, réserves, nourriture, stockage, prédation, renard roux, Vulpes vulpes, oiseaux marins

Traduit pour la revue Arctic par Nésida Loyer.

\section{INTRODUCTION}

The hoarding of food is common among a variety of avian and mammalian species (Andersson and Krebs, 1978; Roberts, 1979; Smith and Reichman, 1984; Vander Wall, 1990). Food hoarding is a highly developed and clearly adaptive behaviour for species relying on prey whose abundance fluctuates greatly (Sherry, 1985). By hoarding surplus food, an animal helps insure survival during periods of prey scarcity (Morse, 1980).

Two behavioural strategies of food hoarding have been differentiated (Morris, 1962). Larder hoarding involves storing many prey in one or a few discreet, clumped locations, whereas scatter hoarding involves concealing individual prey loads in locations dispersed over a wide area (Vander Wall, 1990). Scatter hoards are typically not defended, although their placement within territory boundaries reduces theft. Larder hoards, being clumped and located within an animal's area of greatest activity (e.g., near den sites), are more likely to be defended. These general associations have led to the hypothesis that it is more efficient for territorial animals to defend larders and for nonterritorial animals to disperse hoards that are less likely to be depleted by competitors
(Tinbergen, 1965; Stapanian and Smith, 1978; Hurley and Robertson, 1987; Waite, 1988).

Food hoarding among canids has commonly been described as involving stereotypical behaviour (Vander Wall, 1990). Both red foxes (Vulpes vulpes) and arctic foxes (Alopex lagopus) scatter hoard prey and store prey in larders (Osgood et al., 1915; Freuchen, 1935; Murie, 1936; Braestrup, 1941; Scott, 1943; Pedersen, 1966; Stephenson, 1970; Henry, 1976; Macdonald, 1976; Maccarone and Montevecchi, 1981; Quinlan and Lenhausen, 1982). These findings suggest that hoarding behaviour is flexible and not species-specific or tightly linked with territorial behaviour (Hurley and Robertson, 1987; see also Lockner, 1972; Kramer and Nowell, 1980). Flexibility in hoarding behaviour within a species may provide insight into the factors involved in the selection and expression of hoarding behaviour in these two closely related canid species.

This paper provides new data on hoarding behaviour of red and arctic foxes in large seabird colonies and reviews previous accounts of their hoarding behaviour to evaluate environmental influences on larder hoarding. Such an approach is needed because observing the predatory behaviour of carnivores is difficult.

\footnotetext{
${ }^{1}$ Biopsychology Programme, Departments of Psychology and Biology, Memorial University of Newfoundland, St. John's, Newfoundland A1B 3X9, Canada

${ }^{2}$ Present address: Department of Zoology, University of Stockholm, S-106 91 Stockholm, Sweden

(C) The Arctic Institute of North America
} 


\section{STUDY AREAS}

Baccalieu Island $\left(\sim 6.3 \times 1 \mathrm{~km}, 48^{\circ} 07^{\prime} \mathrm{N}, 54^{\circ} 12^{\prime} \mathrm{W}\right)$ is situated $\sim 3.2 \mathrm{~km}$ from the mainland off the northeast tip of Newfoundland's Avalon Peninsula. The island's habitats feature barren heath, boreal forest (primarily balsam fir, Abies balsamea, and white spruce, Picea glauca), and grassyhummocked slopes (Sklepkovych and Montevecchi, 1989). The densest concentrations of seabirds occur along the southeastern portion of the island, where grassy slopes and steep cliffs predominate. The Low Arctic climate of Newfoundland's east coast involves cool, foggy summers and harsh winters (Banfield, 1983). In some years, during late winter and spring, pack ice covers the water between Baccalieu Island and the mainland.

The principal burrowing species breeding on the island are Leach's storm-petrels (Oceanodroma leucorhoa, more than 3000000 breeding pairs) and Atlantic puffins (Fratercula arctica, about 30000 breeding pairs), which outnumber cliff-nesting species such as black-legged kittiwakes (Rissa tridactyla), common and thick-billed murres (Uria aalge and U. lomvia) and northern gannets (Sula bassana; Montevecchi and Tuck, 1987; Cairns et al., 1989; Sklepkovych and Montevecchi, 1989). Storm-petrels nest in different densities in different habitat types, but burrow nests are found nearly all over the island (Sklepkovych and Montevecchi, 1989). The seabird breeding period on Baccalieu Island generally extends from about April to October. The first substantiated record of foxes on the Baccalieu Island can be dated to 1914, when a fox-farming permit was issued to a local resident by the Newfoundland Game and Inland Fisheries Board (Montevecchi and Tuck, 1987). Red foxes cross pack ice and have been resident on Baccalieu Island since 1959 (Maccarone and Montevecchi, 1981; Sklepkovych, 1986). Otters (Lutra canadensis) are the only other nonhuman mammals known to inhabit the island. House mice (Mus musculus) were present in 1960, but were exterminated that same year (R. Hyde, pers. comm 1984). The absence of coastal beaches and mammalian prey limits the diet of resident foxes to seabirds, some landbirds, berries, and occasional discards of the lighthouse keepers. A minimum of three breeding pairs of foxes were known to live on the island from the late 1970s through the early 1980s. Funk Island $\left(49^{\circ} 46^{\prime} \mathrm{N}, 53^{\circ} 11^{\prime} \mathrm{W}\right)$ is a small, isolated seabird sanctuary located $60 \mathrm{~km}$ off the northeast coast of Newfoundland; nine seabird species breed on the island (Montevecchi and Tuck, 1987).

\section{METHODS}

From 1978 through 1982, we recorded the food hoarding behaviour of red foxes on Baccalieu Island while conducting research on seabird ecology. From 1983 through 1986, the predatory behaviour of foxes was studied more intensively (Sklepkovych, 1986). We observed nine individual foxes that were readily identified by their physical characteristics (e.g., pelage markings) and region of activity, for a total direct observation time of more than 150 hours. Hoards were located by following foxes and through active searching, as well as by chance encounter. Prey identification of hoarded food items was made in the field, and we replaced all stored food items immediately after inspecting them to minimize disturbance to foxes.

The absence of small mammals (e.g., mice, voles) was confirmed by setting traps in four different habitats over 200 trap-nights. Fox scats and prey remains were cleared prior to the 1983 study period along two standard routes extending over much of the island. Prey remains were identified as fox predation using the following characteristics: the presence of canine teeth marks; urine or scat markings near or on the remains; and decapitation or wing clipping from the body. Remains not clearly identifiable (e.g., feather tufts) were not included in the analysis, as they may have been killed by avian predators. Scats were collected along the two standard routes, and the frequency of occurrence of prey type and the weight of undigested matter were used in analyses (Lockie, 1959; Floyd et al., 1978; Kennedy and Carbyn, 1981). Avian prey species were identified by beaks, bones, and feathers, and by microstructure examination of downy barbules (Chandler, 1916; Stauch, 1985). Vegetable matter, insect remains, eggshell fragments, and marine organisms were also examined and weighed. Leach's storm-petrel nest burrows were checked for occupancy during May, June, and October 1984 and February 1985.

Observations of the predatory and hoarding behaviour of the arctic fox on Funk Island during August 1988 provided supplemental information on caching behaviour. We reviewed published accounts of food caching behaviour by red and arctic foxes to provide data on associations between hoarding strategies and environmental factors.

\section{RESULTS AND DISCUSSION}

Red foxes on Baccalieu Island were commonly seen scatter hoarding prey. Of 67 observed storm-petrel captures made by two individuals, $22(33 \%)$ were eaten, although wing and leg remains were often discarded and left scattered above ground. All but two of the remaining 45 birds were partially eaten before being cached in scatter hoards, and at least 3 (7\%) of these items were re-cached within one hour. Twelve (28\%) of the scatter hoards were recovered within 24 hours; $17(41 \%)$ within 48 hours; 22 (53\%) within one week; and 26 (62\%) within two weeks. Only one of the remaining hoards was emptied during the third week, and whether or not foxes later recovered the remaining items is unknown.

Red foxes on Baccalieu Island also used larder hoards, as first reported by Maccarone and Montevecchi (1981). We found and examined 11 larder hoards on Baccalieu Island. Larder sites commonly consisted of one to three large holes within a few metres of each other. Usually located in areas of greatest fox activity, along the southeastern portion of the 
TABLE 1. Summary of prey composition found in larder hoards of red foxes on Baccalieu Island, Newfoundland.

\begin{tabular}{|c|c|c|c|c|c|c|c|c|}
\hline \multicolumn{2}{|l|}{ Date } & \multirow{2}{*}{$\begin{array}{c}\begin{array}{c}\text { Leach's } \\
\text { storm-petrel }\end{array} \\
302\end{array}$} & \multirow{2}{*}{$\begin{array}{c}\text { Atlantic puffin } \\
15\end{array}$} & \multirow{2}{*}{$\begin{array}{c}\begin{array}{c}\text { Black-legged } \\
\text { kittiwake }\end{array} \\
2\end{array}$} & \multirow{2}{*}{$\begin{array}{c}\text { Common murre } \\
1\end{array}$} & \multirow[t]{2}{*}{ Northern gannet } & \multirow[t]{2}{*}{$\begin{array}{c}\text { Passerine } \\
\text { (fox sparrow) }\end{array}$} & \multirow{2}{*}{$\begin{array}{r}\text { Totals } \\
320\end{array}$} \\
\hline June & 1978 & & & & & & & \\
\hline June & 1979 & 30 & 3 & 5 & 1 (chick) & & 1 & 40 \\
\hline August & 1980 & 27 & 29 & & & & & 56 \\
\hline August & 1980 & 15 & 9 & 1 & 1 & & & 26 \\
\hline May & 1983 & 6 & & & & & & 6 \\
\hline June & 1983 & 15 & 5 & 3 & 1 & 1 & & 25 \\
\hline July & 1983 & 5 & 1 & & & & & 6 \\
\hline May & 1984 & 101 & 1 & 3 & & 1 & & 106 \\
\hline October & 1984 & 25 & & & & & & 25 \\
\hline October & 1984 & 23 & 4 & 1 & & & & 28 \\
\hline June & 1985 & 385 & 6 & 5 & & & & 396 \\
\hline \multirow{2}{*}{\multicolumn{2}{|c|}{$\begin{array}{l}\text { Totals } \\
\text { Overall Percentages }\end{array}$}} & 934 & 73 & 20 & 4 & 2 & 1 & 1034 \\
\hline & & 90 & 7 & 2 & $<1$ & $<1$ & $<1$ & \\
\hline
\end{tabular}

island where the largest seabird concentrations occur, the larder sites were typically situated along or within coniferous forest habitat. One extensive larder found in 1985 consisted of 16 holes, in which 385 of $396(97 \%)$ of the carcasses were Leach's storm-petrels. A large larder found in 1978 consisted of 320 avian carcasses, again almost all (94\%) Leach's storm-petrels. Nine of the 11 larder hoards found on Baccalieu Island contained 25 or more birds (Table 1).

Two types of larder hoards were noted. The first type consisted of one or more holes, occurring naturally or actively dug by foxes below large boulders. The second comprised a number of scattered holes actively dug by foxes in the soil to depths of up to $\sim 1 \mathrm{~m}$. Larder holes of the latter category were generally structured vertically, though some contained horizontal compartments at their base. The foxes made no attempts to conceal stored food at ground level by covering hole entrances with debris, as is typical when foxes scatter hoard (Henry, 1976, 1977; Macdonald, 1976). Carcasses were either stuffed underneath boulders, or stuffed and piled within larder holes. At some sites, prey parts (e.g., wings) and partial carcasses were scattered above ground around larder hoards.

Burrow-nesting birds comprised the vast bulk of food items in red fox larders on Baccalieu Island (Table 1). Leach's storm-petrels and Atlantic puffins made up $81 \pm 19 \%$ SE and $14 \pm 17 \%$ SE, respectively, of prey found in larders $(\mathrm{N}=11)$. Larder hoards located near a major Atlantic puffin colony showed a disproportionately high number of puffins (53/344, or $15 \%)$ compared to larders elsewhere (20/590, or $3 \%$ ). Cliff-nesters were much less important components in larder hoards. Black-legged kittiwakes made up $3 \pm 1 \%$ of lardered prey, whereas larger species, such as common murres and northern gannets, were much less frequent $(\sim 1 \%)$. Only a single passerine, a fox sparrow (Passarella iliaca), was found among the lardered prey. The proportion of storm-petrels found in larder hoards (560/592, or 95\%) was significantly higher than the proportions of storm-petrel remains attributed to fox predation $\left(564 / 632\right.$, or $\left.89 \% ; \chi^{2}{ }_{1}=10.5, p<.01\right)$ and in scats $\left(269 / 307\right.$, or $\left.88 \% ; \chi^{2}=12.5, p<.01\right)$ during the same period, suggesting that foxes may have hoarded proportionally more storm-petrels than they ate, or may have eaten proportionally more of less common prey than they hoarded.

Eight of 11 larder hoards were located within $50 \mathrm{~m}$ of previously used or potential dens. The provisioning and use of larders by foxes was difficult to assess. At one larder found in May 1984, denning activity ceased and 94\% (85/101) of
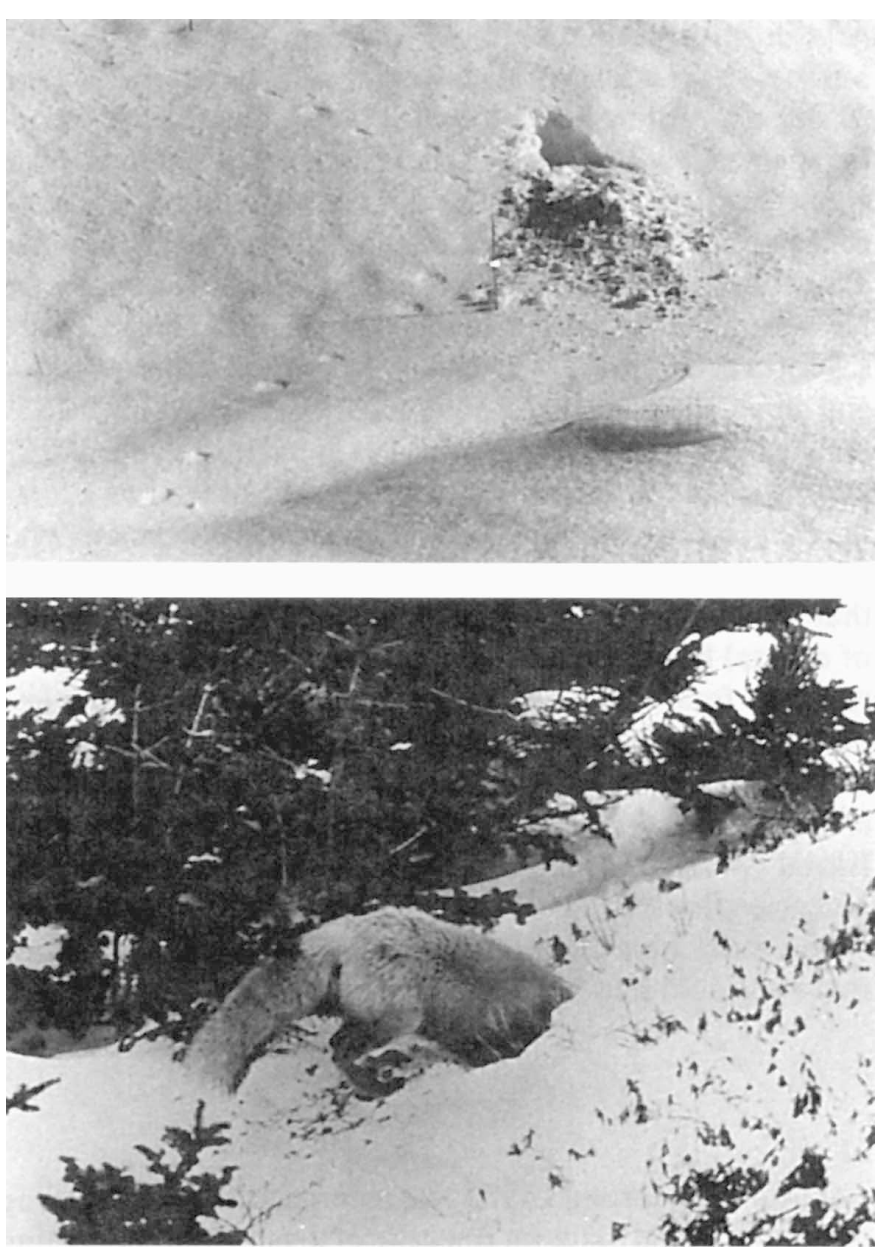

FIG. 1. Utilization of hoarded food in winter by red foxes. Upper) tracks in snow lead to and from a utilized cache; Lower) recovering cached food in winter (Photographs by B.O. Sklepkovych). 
TABLE 2. Hoard type, prey groups, and environmental features associated with food caching by red and arctic foxes.

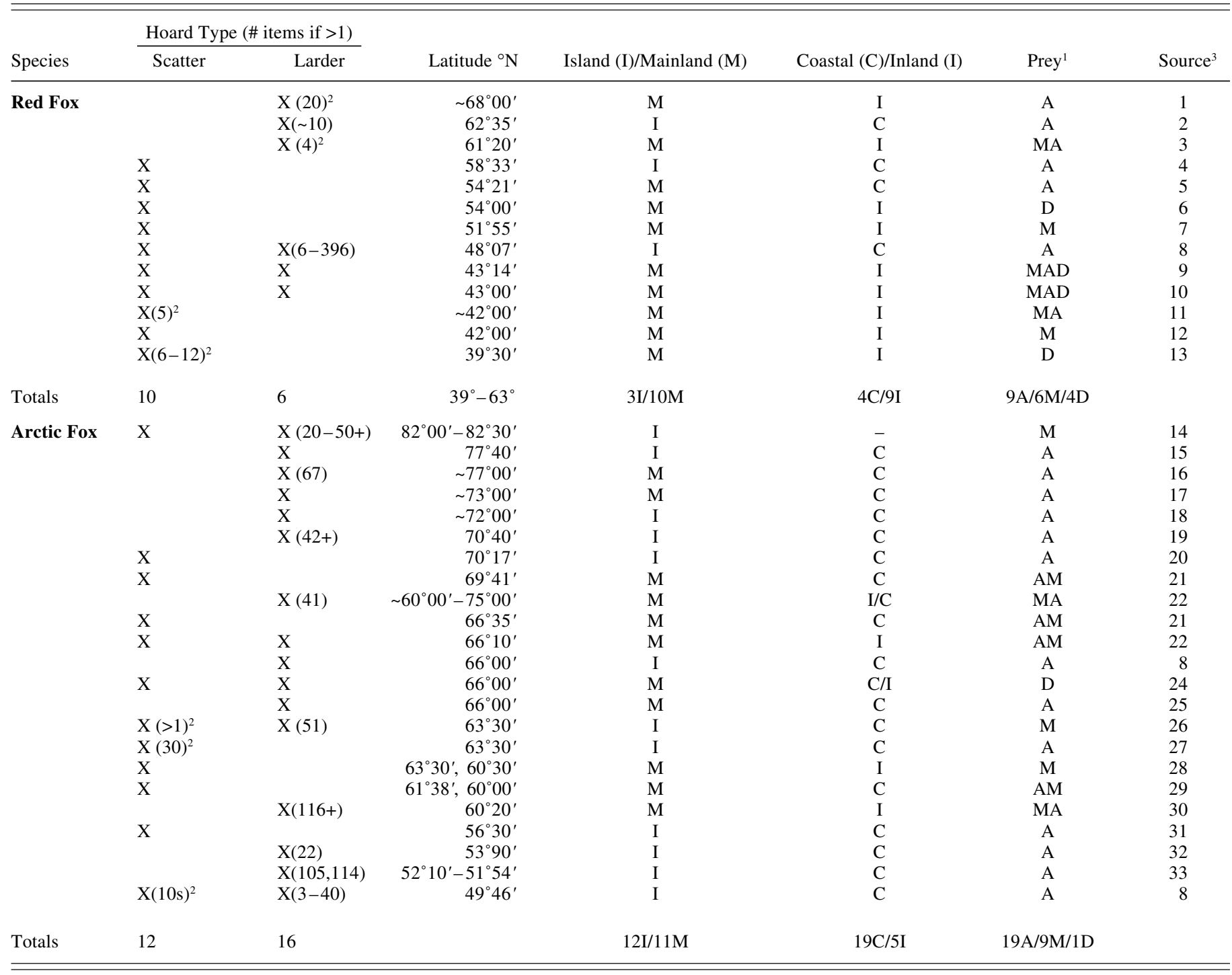

${ }^{1} \mathrm{~A}=$ avian, $\mathrm{M}=$ mammalian, $\mathrm{D}=$ diverse

${ }^{2}$ Caches with multiple prey items that are stored away from denning areas are classified as scatter hoards (see text)

${ }^{3}$ Sources: 1) Lund, 1962; 2) Gaston et al., 1985; 3) Sande, 1943; 4) Petersen, 1982; 5) Kruuk, 1964; Tinbergen, 1965; 6) Henry, 1976; 7) MacDonald, 1976; 8) present study; Maccarone and Montevecchi, 1981; 9) Pils and Martin, 1978; 10) Errington, 1935, 1937, 1967; 11) Scott, 1943; 12) Murie, 1936; 13) Fisher, 1951; 14) Fielden, 1877; 15) Gibson, 1922; 16) Freuchen, 1935; 17) McClintock, 1859 (in Braestrup, 1941); 18) Dubrovskii, 1937; 19) Pedersen, 1966; 20) Quinlan and Lenhausen, 1982; 21) Burgess, 1984; 22) Macpherson, 1969; 23) Schamel and Tracy, 1986; 24) Hersteinsson and MacDonald, 1982; 25) Muller, 1966; 26) Stephensen, 1970; 27) J. Piatt and B. Roberts, pers. comm. 1992; 28) Frafjord, 1986; 29) Stickney, 1985, 1988; 30) Høst, 1935; 31) Murie, 1959; 32) Birkhead, 1993; 33) Osgood et al., 1915.

prey items were missing two weeks after initial discovery, a possible reaction to human presence. Despite repeated visits and watches at most larders and den sites, on only one occasion was a fox observed contributing more than once to a larder. Two storm-petrels (a single prey load) were directly deposited into a larder hole, after which the fox departed, returning within five minutes with a freshly caught stormpetrel. The fox partially ate the bird, leaving its decapitated remains above ground. Foxes were observed depositing single prey in a larder hole and examining larder holes without utilizing prey. An adult was observed provisioning kits at the den with a storm-petrel retrieved from a larder $\sim 30 \mathrm{~m}$ away.

Most carcasses found in larders were intact, although some were decapitated or had wings removed (see also Sargeant, 1972). Food items uncovered from beneath larder heaps appeared older, showing signs of partial decomposition and dehydration and in some cases signs of insect infestation. Nevertheless, lardered birds appeared to decompose little over the summer and autumn. Three freshly killed stormpetrels placed in a crevice under a rock in July 1986 showed 
limited dehydration and were well preserved when checked in October 1986. The microclimate of the larder holes, noticeably cooler than ambient temperatures, probably aided in preserving stored foods.

Foxes were often seen during winter digging beneath the snow to uncover cached prey. Foods uncovered by foxes during such diggings reflected recently scatter hoarded foods which appeared to be of little value to foxes (e.g., wings). Occasionally, foxes would dig beneath the snow to excavate storm-petrel burrows. Rarely were these attempts known to be successful. Of 21 instances when foxes were observed excavating storm-petrel burrows in February, only one egg was found. When checked in mid-October, 74\% (55/74) of previously occupied storm-petrel nests were empty, and in February, $6 \%$ of burrows contained only eggshell fragments. Only one of 16 snow excavations greater than $0.5 \mathrm{~m}$ in depth took place adjacent to a potential den site, suggesting that prey acquisition was the primary motivation for digging (Fig. 1). An additional and related factor implicates larder-hoard use by foxes during winter. Storm-petrels, which are not present on Baccalieu Island from November to April, made up a minimum of $53-63 \%(\mathrm{~N}=52)$ of fresh scat collected in February. The contribution of scatter hoarded and scavenged food appears to provide little nutrition for foxes on Baccalieu Island during winter. Some larder holes may freeze, forcing foxes to wait until a thaw before retrieving food items.

The arctic fox encountered on Funk Island also preyed primarily on the smallest burrow-nesting species present (i.e., Atlantic puffins). Three birds (two puffins, one murre) were cached in a den, and five puffins were found under large rocks at another possible temporary den site, where 20 puffins were found scattered within $12 \mathrm{~m}^{2}$. Some puffins were also partially buried. The protection afforded by cliff-nesting and prey abundance were minor factors on Funk Island, where the abundant cliff-nesting species (e.g., common murres) nest on level terrain (fully accessible to the fox), and where the puffin population is three orders of magnitude smaller than the murre population (Montevecchi and Tuck, 1987).

Foxes and other opportunistic species exhibit flexible hoarding behaviour. We found individual red and arctic foxes using both scatter- and larder-hoarding techniques. Food hoarding behaviour varies considerably, within a species as well as among canid species, in response to behavioural and environmental circumstances (Macdonald, 1976), particularly when viewed over the animals' geographic range. Accordingly, individual and population variations in hoarding behaviour may exemplify adaptation and adjustments to local ecological conditions. Despite the limited availability of quantitative data, many examples of hoarding flexibility are found among red and arctic foxes (Table 2).

Larder hoarding has been reported more frequently for arctic foxes, that presumably select this strategy at high latitudes characterized by extreme seasonal shifts in food conditions (Braestrup, 1941); prey includes small, burrowing seabirds (i.e., auklets, storm-petrels, puffins; Gibson, 1922; Freuchen, 1935; Murie, 1959; Savage and Cooper, 1982; present study) and voles and lemmings (Fielden, 1877;
Stephenson, 1970). The largest documented arctic fox larder contained 107 least auklets (Aethia pusilla), 18 crested auklets (Aethia cristaletta), 7 fork-tailed storm-petrels (Oceanodroma furcata), 3 tufted puffins (Lunda cirrhata) and a horned puffin (Fratercula corniculata; Murie, 1959). Arctic foxes have also been described scatter hoarding (e.g., Quinlan and Lenhausen, 1982) and may do so at a young age ( $6 \mathrm{wk}$ : Macdonald, 1976; Frafjord, 1992). In areas of severely limited food resources (e.g., Fennoscandia; Hersteinsson et al., 1989), only a small proportion of active time is dedicated to hoarding food during the denning period (Frafjord, 1992; Sklepkovych, unpubl. data).

Scatter hoarding and subsequent recovery of food items have been well described for red foxes (Scott, 1943; Macdonald, 1976; Henry, 1977). Tendencies toward surplus killing (Stickney, 1988) and larder hoarding have also been observed (e.g., Fisher, 1951; Lund, 1962; Errington, 1967; see Table 2). Being opportunistic predators (Hersteinsson and Macdonald, 1982), red foxes will make larders under environmental conditions similar to those under which arctic foxes larder hoard prey. Scatter and larder hoarding have often been viewed as distinct, though they probably represent aspects of a behavioural continuum determined largely by spatial and temporal dispersion of prey (Kramer and Nowell, 1980; Hurley and Robertson, 1990; Vander Wall, 1990).

Future studies of fox ecology should carefully record hoarding behaviour to gain greater insight into its flexibility and potential role in enhancing fitness. Red foxes are currently expanding their range northward (Macpherson, 1964) and are well established in arctic regions (Skrobov, 1960; Banfield, 1974), where they often displace arctic foxes (Chirkova, 1968; Ostbye et al., 1978; Schamel and Tracey, 1986; Frafjord et al., 1989). We conclude that hoarding behaviour is quite flexible and largely determined by food availability, and that more intraspecific variation in hoarding strategy will be found.

\section{ACKNOWLEDGEMENTS}

Research was supported by the Department of Psychology, Memorial University of Newfoundland (thank you, Gordon Barnes) and through a Natural Sciences and Engineering Research Council of Canada (NSERC) Individual Operating Grant awarded to W.A. Montevecchi. The Department of Zoology at the University of Stockholm and the Swedish Institute provided additional support and funding to B.O. Sklepkovych during manuscript preparation (special thanks to Prof. B. Ganning and F. Dinnetz). We thank John Piatt for unpublished data, and Alice Stickney for an insightful review of previous drafts of this paper. The Canadian Coast Guard provided helicopter transportation to Baccalieu Island, where the hospitality of the lighthouse keepers (Raymond Hyde, Linus Walsh, Felix Noonan, Eric Blundon, and Pat Rice) was deeply appreciated. We thank the Newfoundland and Labrador Parks Division (Glen Ryan and Doug Ballam) for permission to work on Baccalieu Island, a Provisional Provincial Ecological Reserve. This paper is dedicated to the memory of Felix Noonan, keeper of the light. 


\section{REFERENCES}

ANDERSSON, M., and KREBS, J.R. 1978. On the evolution of hoarding behaviour. Animal Behaviour 26:707-711.

BANFIELD, A.W.F. 1974. The mammals of Canada. Toronto: University of Toronto Press. 438 p.

BANFIELD, C.E. 1983. Climate. In: South, G.R., ed. Biogeography and ecology of the Island of Newfoundland. The Hague: Junk. 37-106.

BIRKHEAD, T.R. 1993. Great Auk Islands: A field biologist in the Arctic. London: Poyser.

BRAESTRUP, F.W. 1941. A study of the arctic fox in Greenland. Meddelelser om Grønland 131. 98 p.

BURGESS, R.M. 1984. Ecology of arctic foxes (Alopex lagopus) at Demarcation Bay, Alaska. Cooperative Wildlife Research Unit Progress Report 36. 9-12.

CAIRNS, D.K., MONTEVECCHI, W.A., and THRELFALL, W. 1989. Researcher's guide to Newfoundland seabird colonies. Memorial University of Newfoundland Occasional Papers in Biology No. 14.

CHANDLER, A.C. 1916. A study of the structure of feathers with reference to their taxonomic significance. University of California Publications in Zoology 13. 243-446.

CHIRKOVA, A.F. 1968. The relationship between arctic fox and red fox in the far North. Problems of the North 11:129-131.

DUBROVSKII, A.N. 1937. The arctic fox (Alopex lagopus $($ L.)) and arctic fox trapping in Novaya Zemlya. Transactions Arctic Institute Leningrad 77:7-31.

ERRINGTON, P.L. 1935. Food habits of mid-west foxes. Journal of Mammalogy 16:192-200.

1937. Food habits of Iowa red foxes during a drought summer. Ecology 18:53-61.

- 1967. Of predation and life. Ames, Iowa: Iowa State University Press. 277 p.

FIELDEN, H.W. 1877. On the mammalia of North Greenland and Grinnell Land. Zoologist 1:313-321.

FISHER, H.I. 1951. Notes of the red fox (Vulpes vulpes) in Missouri. Journal of Mammalogy 32: 296-299.

FLOYD, T.J., MECH, D.L., and JORDAN, P.A. 1978. Relating wolf scat content to prey consumed. Journal of Wildlife Management 42:528-532.

FRAFJORD, K. 1986. An ethogram of arctic fox behaviour in the denning area. Meddelelser fra Norsk Viltforskning 15:1-52.

- 1992. Den activity and behavior of arctic fox (Alopex lagopus) pups: Implications of food availability. Polar Biology 12:707-712.

FRAFJORD, K., BECKER, D., and ANGERBJORN, A. 1989. Interactions between arctic and red foxes in Scandinaviapredation and aggression. Arctic 42:354-356.

FREUCHEN, P.1935. Report of the first Thule Expedition: Zoology. Meddelelser om Grønland 51:389-411.

GASTON, A.J., CAIRNS, D.K., ELLIOT, R.D., and NOBLE, D.G. 1985. A natural history of Digges Sound. Canadian Wildlife Service Report Series No. 46.

GIBSON, L. 1922. Bird notes from north Greenland. Auk 39: $350-363$.
HENRY, J.D. 1976. Adaptive strategies in the behaviour of the red fox (Vulpes vulpes L.). Ph.D. thesis, The University of Calgary, Alberta, Canada.

. 1977. The use of urine marking in the scavenging behaviour of the red fox (Vulpes vulpes). Behaviour 61:82-105.

HERSTEINSSON, P., and MacDONALD, D.W. 1982. Some comparisons between red and arctic foxes, Vulpes vulpes and Alopex lagopus, as revealed by radio telemetry. Symposium of the Zoological Society, London 49:259-289.

HERSTEINSSON. P., ANGERBJORN, A., FRAFJORD, K., and KAIKUSALO, A. 1989. The arctic fox in Fennoscandia and Iceland: Management problems. Biological Conservation 49: 67-81.

HØST, P. 1935. Trekk av dyrelivet paa Hardangervidda. Norsk Jaeger og Fisker-Forenings Tidsskrift 64:201-202.

HURLEY, T.A., and ROBERTSON, R.J. 1987. Scatter hoarding by territorial red squirrels: A test of the optimal model. Canadian Journal of Zoology 65:1247-1252.

HURLEY, T.A., and ROBERTSON, R.J. 1990. Variation in the food hoarding behaviour of red squirrels. Animal Behaviour 26:91-97.

KENNEDY, A.J., and CARBYN, L.N. 1981. Identification of wolf prey using hair and feather remains with special reference to western Canadian national parks. Canadian Wildlife Service International Report.

KRAMER, D.L., and NOWELL, W. 1980. Central place foraging in the eastern chipmunk, Tamias striatus. Animal Behaviour 28:772-778.

KRUUK, H. 1964. Predators and anti-predator behaviour of the black-headed gull (Larus ridibundus). Behaviour Supplement $11: 1-130$.

LOCKIE, J.D. 1959. The estimation of the food of foxes. Journal of Wildlife Management 23:224-227.

LOCKNER, F.R. 1972. Experimental study of food hoarding in the red-tailed chipmunk, Eutamias ruficaudus. Zeitschrift für Tierpsychologie 31:410-418.

LUND, H.M. 1962. The red fox in Norway II. Meddelelser fra Statens Viltundersokelser 2. No. 12.

MACCARONE, A.D., and MONTEVECCHI, W.A. 1981. Red fox predation on cliff- and burrow-nesting seabirds on Baccalieu Island, Newfoundland. Canadian Field-Naturalist 95:352-353.

MacDONALD, D.W. 1976. Food caching by red foxes and some other carnivores. Zeitschrift für Tierpsychologie 42:170-185.

MACPHERSON, A.H. 1964. A northward range extension of the red fox in the eastern Canadian Arctic. Journal of Mammalogy 45:138-140.

. 1969. The dynamics of Canadian arctic fox populations. Canadian Wildlife Service Report Series No. 8.

MONTEVECCHI, W.A., and TUCK, L.M. 1987. Newfoundland birds: Exploitation, study, conservation. Cambridge, Massachusetts: Nuttall Ornithological Club. 277 p.

MORRIS, D. 1962. The behaviour of the green agouchi (Myoprocta pratti) with special reference to scatter hoarding. Proceedings of the Zoological Society (London) 39:701-732.

MORSE, D.H. 1980. Behavioral mechanisms in ecology. Cambridge: Harvard University Press. 383 p. 
MULLER, R. 1966. Vildtet og Jagten i Syngrønland. Copenhagen. MURIE, A. 1936. Following fox trails. University of Michigan Miscellaneous Publications in Zoology No. 32.

MURIE, O.J. 1959. Fauna of the Aleutian Islands and Alaska Peninsula. North American Fauna No. 61.

OSGOOD, W.H., PREBLE, E.A., and PARKER, G.H. 1915. The fur seals and other life on the Pribilof Islands, Alaska, in 1914. Bulletin Bureau of Fisheries, United States Department of Commerce 34. 172 p.

OSTBYE, E., SKAR, H.J., SVALASTOG, D., and WESTBY, K. 1978. Arctic fox (Alopex lagopus) and red fox (Vulpes vulpes) on Hardangervidda: Den ecology, distribution and population status. Meddelelser fra Norsk Viltforskning 3:1-66.

PEDERSEN, A. 1966. Polar animals. New York: Taplinger. 188 p.

PETERSON, M.R. 1982. Predation on seabirds by red foxes on Shaiak Island, Alaska. Canadian Field-Naturalist 96:41-45.

PILS, C.M., and MARTIN, M.A. 1978. Population dynamics, predator-prey relationships and management of the red fox in Wisconsin. Wisconsin Department of Natural Resources, Technical Bulletin 105.

QUINLAN, S.E., and LENHAUSEN, W.A. 1982. Arctic fox, Alopex lagopus, predation on nesting common eiders, Somateria mollissma, at Icy Cape, Alaska. Canadian Field-Naturalist 96:462-466.

ROBERTS, R.C. 1979. The evolution of avian food-storing behavior. American Naturalist 114:418-438.

SANDE, J.O. 1943. Hvordan reven hamstrer om vinteren. Naturen 67:255-256.

SARGEANT, A.B. 1972. Red fox spatial characteristics in relation to waterfowl predation. Journal of Wildlife Management 42: 520-527.

SAVAGE, H.G., and COOPER, J.C. 1982. Bones from an arctic fox den on Knight's Hill in northern Manitoba. Canadian FieldNaturalist 96:342-344.

SCHAMEL, D., and TRACY, D.M. 1986. Encounters between arctic foxes, Alopex lagopus, and red foxes, Vulpes vulpes. Canadian Field-Naturalist 100:562-563.
SCOTT, T.G. 1943. Some food coactions of the Northern Plains red fox. Ecological Monographs 13:427-479.

SHERRY,D.F. 1985. Food storage in birds and mammals. Advances in the Study of Behavior 15:153-188.

SKLEPKOVYCH, B.O. 1986. The predatory behaviour and impact of red foxes (Vulpes vulpes) on the breeding seabirds of Baccalieu Island, Newfoundland. M.Sc. thesis (Biopsychology), Memorial University of Newfoundland, St John's, Canada. 190 p.

SKLEPKOVYCH, B.O., and MONTEVECCHI, W.A. 1989. The world's largest documented colony of Leach's storm-petrels on Baccalieu Island, Newfoundland. American Birds 43:38-42.

SKROBOV, V.D. 1960. On the interrelations of the polar fox and the fox in the tundra of the Nenets national region. Zoologicheskii Zhurnal 39:469-471.

SMITH, C.C., and REICHMANN, O.J. 1984. The evolution of food caching by birds and mammals. Annual Review Ecology and Systematics 15:329-351.

STAPANIAN, M.A., and SMITH, C.C. 1978. A model for seed scatterhoarding: Coevolution of fox squirrels and black walnuts. Ecology 59:884-896.

STAUCH, J.G. 1985. The phylogeny of Alcidae. Auk 102:520539.

STEPHENSON, R.O. 1970. A study of the summer food habits of the arctic fox on St. Lawrence Island, Alaska. M.Sc. thesis, University of Alaska, Fairbanks, Alaska, U.S.A. 92 p.

STICKNEY, A. 1985. Ecology and behavior of arctic foxes in goose nesting areas of the Yukon Kuskokwim Delta, Alaska. Alaska Cooperative Wildlife Research Unit Progess Report 37: $11-13$.

- 1988. Foraging behavior and habitat use by arctic foxes near Kokechic Bay, Alaska. Alaska Cooperative Wildlife Research Unit Progress Report 40:5.

TINBERGEN, N. 1965. Von den Vorratskammern des Rotfuchses (Vulpes vulpes L.). Zeitschrift für Tierpsychologie 22:119149.

VANDER WALL, S.B. 1990. Food hoarding in animals. Chicago: University of Chicago Press. 445 p.

WAITE, T.A. 1988. A field test of density-dependent survival of simulated gray jay caches. Condor 90:247-249. 